\title{
Small-bowel cryptococcosis diagnosed by double-balloon endoscopy in patient without human immunodeficiency virus
}

A 45-year-old man presented with a 2-year history of diarrhea and anasarca. His work involved opening tunnels and exploding rocks. He had no cardiovascular abnormalities or proteinuria. Celiac disease and human immunodeficiency virus (HIV) serologies were negative. Total protein $(2.6 \mathrm{~g} / \mathrm{dL})$, albumin $(1.5 \mathrm{~g} / \mathrm{dL})$, ionized calcium $(3.09 \mathrm{mg} / \mathrm{dL})$, vitamin $\mathrm{D}$ $(6.7 \mathrm{ng} / \mathrm{mL})$, and immunoglobulin ( $\mathrm{gM}$ $29 \mathrm{mg} / \mathrm{dL}, \operatorname{lgG} 357 \mathrm{mg} / \mathrm{dL}$, IgA $60 \mathrm{mg} / \mathrm{dL}$ ) levels were low. Sodium and potassium were normal.

Upper gastrointestinal endoscopy demonstrated erosions and patchy, whitish lesions in the second portion of the duodenum, suggestive of lymphangiectasia. Biopsies showed unspecific duodenitis. Colonoscopy was normal.

Computed tomography (CT) demonstrated thickness and lymphatic cystic lesions involving the duodenum, jejunum, pancreas, and retroperitoneum ( Fig. 1). Owing to suspicion of proteinlosing enteropathy, anterograde doubleballoon endoscopy (DBE) was indicated. DBE showed whitish spots and nodularity in the second and third portions of the duodenum, and multiple subepithelial cystic lesions with lymphatic fluid extravasation at biopsy in the fourth portion of the duodenum and up to $150 \mathrm{~cm}$ of the jejunum ( $\triangleright$ Video 1 ). Histopathology revealed lymphomononuclear infiltrate, granuloma (> Fig.2), and spores on mucicarmine and Grocott stains (\$ Fig.3), compatible with Cryptococcus neoformans.

The patient was hospitalized with intense headache, reduced visual acuity, and convulsions. He was diagnosed with systemic Cryptococcus infection, affecting central nervous system, gastrointestinal tract, and lymphatic system. Amphotericin B was given for 21 days with significant clinical improvement, followed by fluconazole $800 \mathrm{mg} /$ day for 1 year. CT and laboratory tests returned to normal.

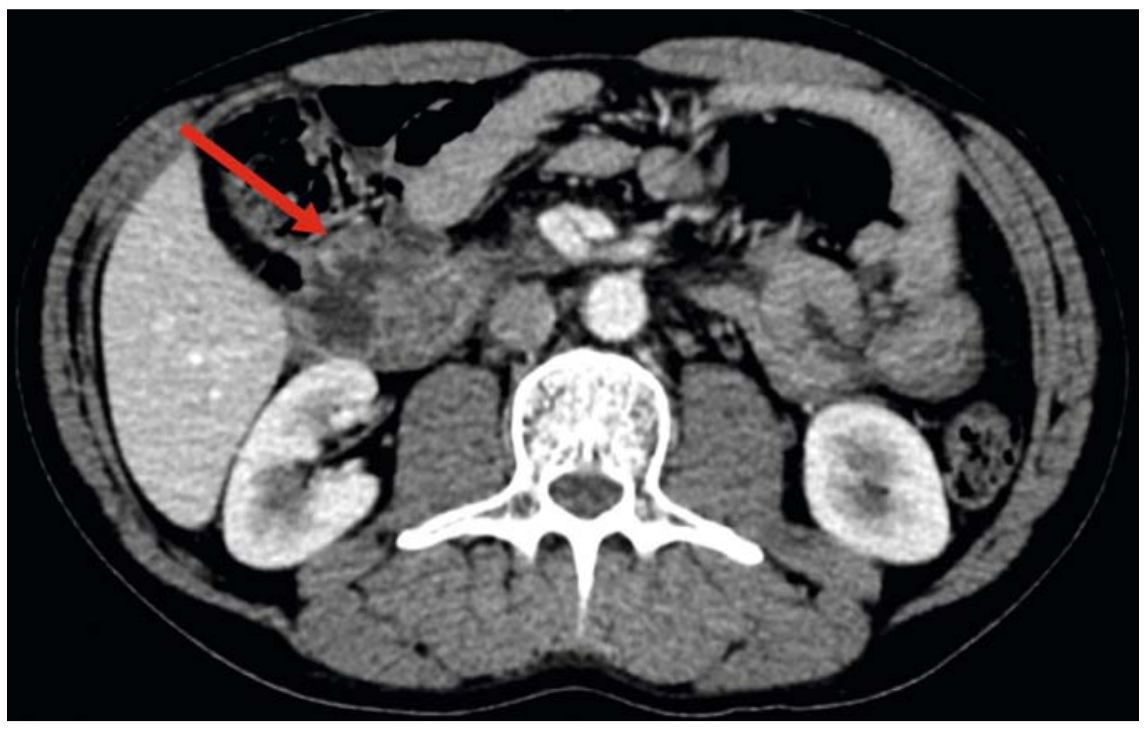

- Fig. 1 Computed tomography demonstrated thickness and lymphatic cystic lesions (arrow) involving the duodenum, proximal jejunum, pancreas, and retroperitoneum.
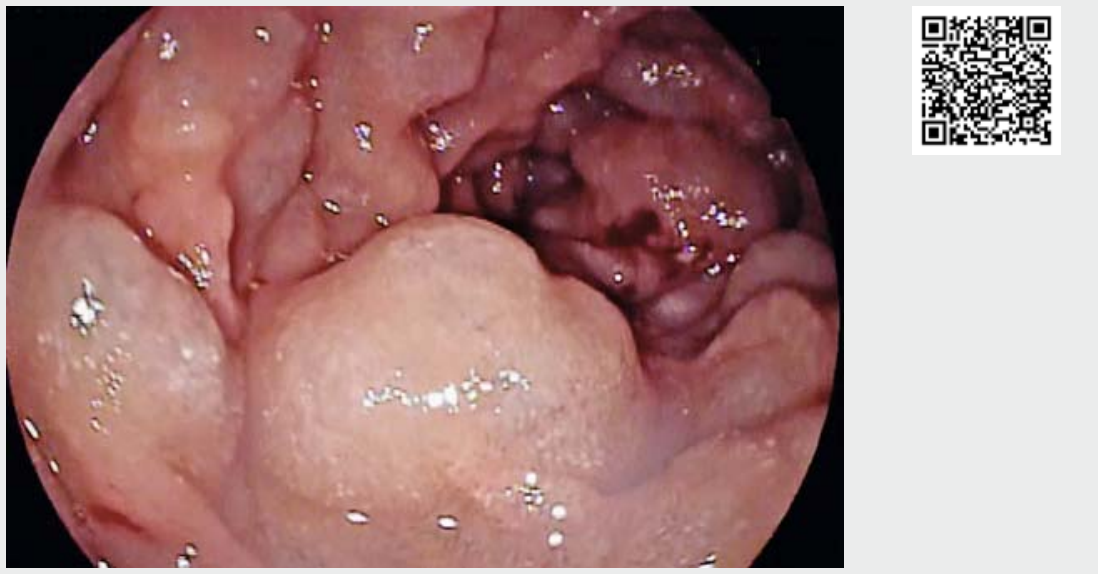

Video 1 Computed tomography showed lymphatic cystic lesions involving the small bowel, confirmed by double-balloon endoscopy. Subepithelial duodenal and jejunal lesions with lymphatic fluid extravasation were observed, with great improvement after treatment.

DBE showed significant improvement ( $\triangleright$ Fig.4), with negative fungal histology. The few reports of disseminated cryptococcosis mostly involve HIV/acquired immunodeficiency syndrome [1, 2]. Gastrointestinal tract symptoms on presenta- tion are seldom described [3,4]. In this case of disseminated cryptococcosis in an immunocompetent, non-HIV patient, DBE was valuable in diagnosing and managing the small-bowel involvement [5]. 


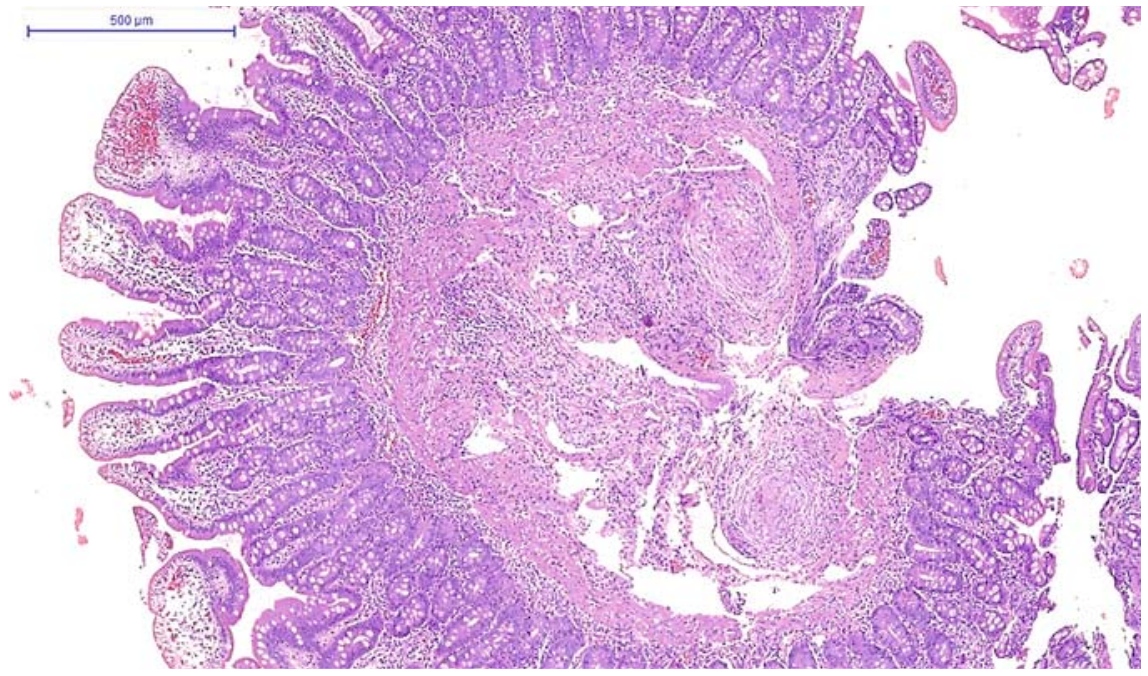

- Fig. 2 Hematoxylin and eosin staining showed lymphomononuclear infiltrate, with traces of granuloma and round organisms.

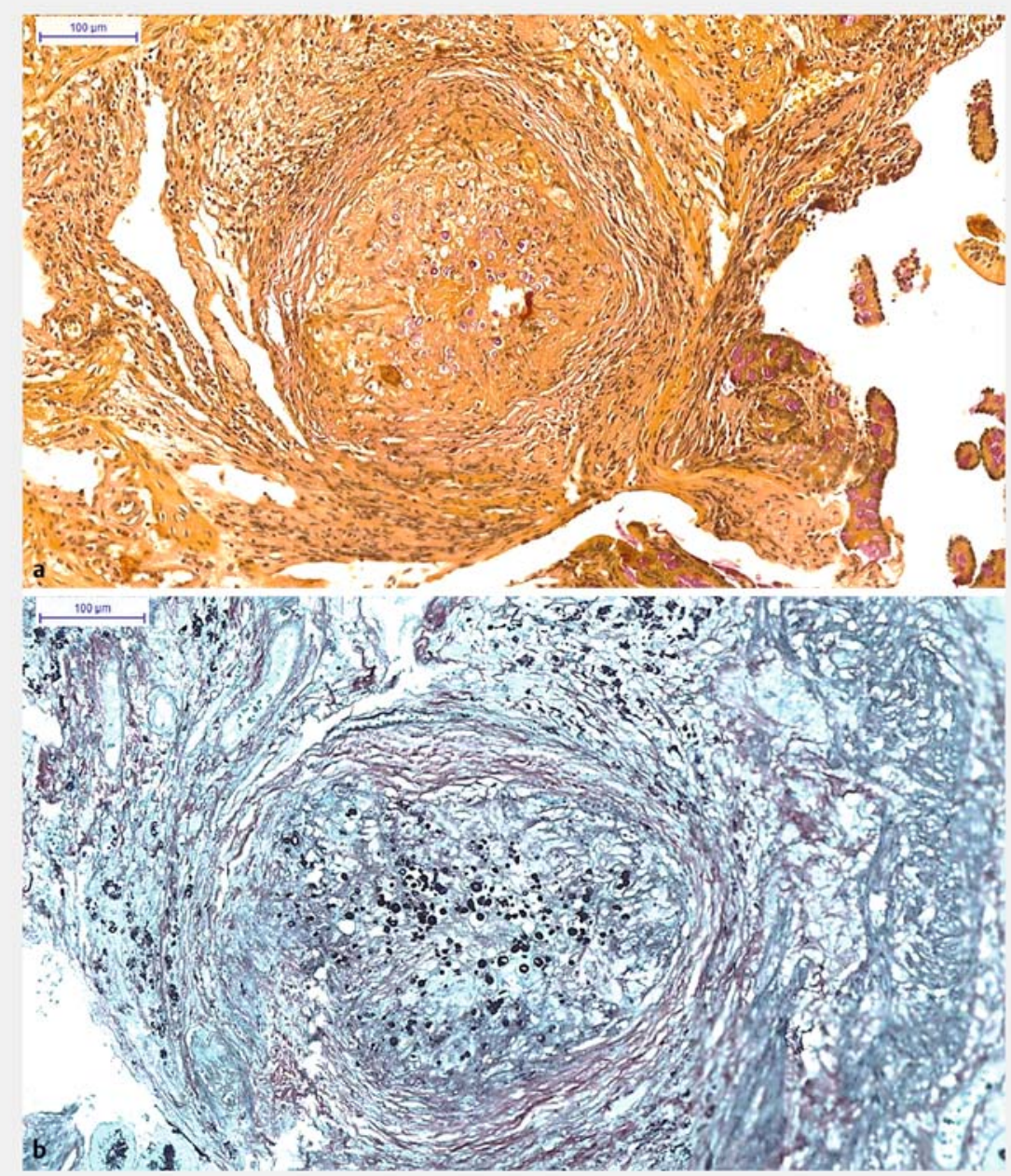

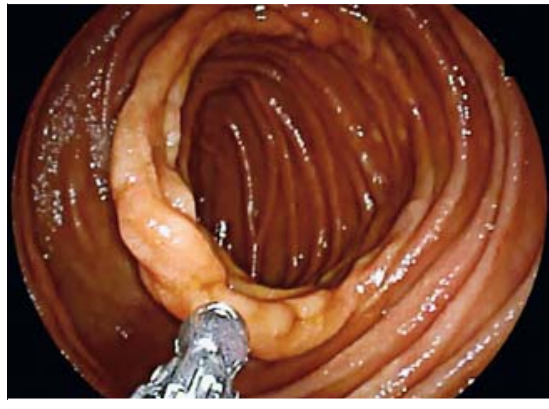

- Fig. 4 Double-balloon endoscopy demonstrated reduction of the lymphatic cystic lesions after 1 year of treatment.

Endoscopy_UCTN_Code_CCL_1AC_2AG

Competing interests

The authors declare that they have no conflict of interest.

The authors

Túlio Riguetti Prazeres ${ }^{1}$, Marcela Almeida Menezes de Vasconcellos' ${ }^{1}$, Marcella Salazar Sousa', Evelin Sánchez Ortiz², Ulysses Ribeiro Junior ${ }^{3}$, Sérgio Carlos Nahas ${ }^{3}$, Adriana Vaz Safatle-Ribeiro ${ }^{1}$

1 Endoscopy Unit, Coloproctology Surgical Division, Department of Gastroenterology, University of São Paulo Medical School

2 Department of Pathology, University of São Paulo Medical School, São Paulo, Brazil

3 Coloproctology Surgical Division, Department of Gastroenterology, University of São Paulo Medical School, São Paulo, Brazil

\section{Corresponding author}

Adriana Vaz Safatle-Ribeiro, MD, PhD

Endoscopy Unit, Department of

Gastroenterology, University of São Paulo

Medical School, Av. Dr. Enéas Carvalho

de Aguiar, 255 Cerqueira Cesar,

05403-000 São Paulo, SP, Brazil

Fax: +55-11-32849885

adriana.safatle@hc.fm.usp.br
- Fig. 3 Staining was suggestive of Cryptococcus neoformans. a Mucicarmine staining revealed the presence of the organism's mucopolysaccharide capsule (in pink). b Grocott staining highlighted the fungal cell wall (in black). 


\section{References}

[1] Girardin M, Greloz V, Hadengue A. Cryptococcal gastroduodenitis: a rare location of the disease. Clin Gastroenterol Hepatol 2010; 8: e28-e29

[2] Li ], Wang N, Hong Q et al. Duodenal cryptococcus infection in an AIDS patient: retrospective clinical analysis. Eur J Gastroenterol Hepatol 2015; 27: 226-229

[3] Tzimas D, Wan D. Small bowel perforation in a patient with AIDS. Diagnosis: small bowel infection with Cryptococcus neoformans. Gastroenterology 2011; 140: 1882-2150

[4] Liu Y, Patel AA, Shaw JC et al. Gastroduodenal Cryptococcus in an AIDS patient presenting with melena. Gastroenterol Res 2013; 6 : $26-28$
[5] Safatle-Ribeiro AV, Iriya K, Couto DS et al. Secondary lymphangiectasia of the small bowel: utility of double balloon enteroscopy for diagnosis and management. Dig Dis 2008; 26: 383-386

Bibliography

Endoscopy 2021; 53: E150-E152

DOI $10.1055 / \mathrm{a}-1216-1048$

ISSN 0013-726X

published online 20.8.2020

(c) 2020. Thieme. All rights reserved.

Georg Thieme Verlag KG, Rüdigerstraße 14,

70469 Stuttgart, Germany
ENDOSCOPY E-VIDEOS

https://eref.thieme.de/e-videos

回回 Endoscopy E-Videos is a free access online section, reporting 田: on interesting cases and new techniques in gastroenterological endoscopy. All papers include a high quality video and all contributions are freely accessible online.

This section has its own submission website at

https://mc.manuscriptcentral.com/e-videos 